\title{
Impact of Intellectual Capital on Mergers and Acquisitions: Evidence from Developed and Emerging Capital Markets
}

\section{Irina Skvortsova}

Faculty member, Faculty of Economic Sciences, School of Finance

$\underline{\text { ORCID }}$

E-mail: irina.v.skvortsova@gmail.com

National Research University Higher School of Economics

Moscow, Russia

\section{Arina Sidelnikova}

Bachelor degree graduate in Economics

$\underline{\text { ORCID }}$

E-mail: allaya@inbox.ru

National Research University Higher School of Economics

Moscow, Russia

Journal of Corporate Finance Research, Vol. 14, No. 2, pp. 35-57 (2020)

DOI: https://doi.org/10.17323/j.jcfr.2073-0438.14.2.2020.35-57

Received 13 May 2020 ｜ Peer-reviewed 20 May 2020 ｜ Accepted 22 May 2020 


\section{Impact of Intellectual Capital on Mergers and Acquisitions: Evidence from Developed and Emerging Capital Markets}

\section{Abstract}

In this article, we analyse the influence of intellectual capital on M\&A performance in developed and emerging capital markets with the use of the event studies and regression analysis methodologies. In contrast to previous research studies in this area, we assess the impact of the components of intellectual capital (human, structural, and relational capital) on firm value as a result of mergers and broaden the scarce level literature on this specific topic. We additionally present a comparative analysis of the influence of intellectual capital components on M\&A performance vis-à-vis the performance of acquirers from developed and emerging capital markets.

Our research sample consists of 194 cross-border deals closed in the period 2010-2018. We compare developed markets based on firms from USA, Canada, Germany, Great Britain, France, Italy and Japan and emerging markets based on firms from China, India, Brazil and Malaysia.

Our findings contribute to the literature in several ways. Firstly, we document a positive and significant dependence between the level of intellectual capital of the target firm and the M\&A performance level of the acquirer, irrespective of the market where the acquirer operates. We provide empirical support for the postulation that the higher the level of intellectual capital of the target firm, the higher M\&A performance of the acquirer will be in both developed and emerging markets. Secondly, we empirically prove that each of the components of intellectual capital of the target firm increases M\&A performance: the higher the level of human, structural or relational capital of the target firm, the higher the M\&A performance level of the acquirer in both developed and emerging capital markets. Thirdly, we show that the level of impact of human capital on M\&A performance is higher for emerging market acquirers, and the impact of structural capital is higher for developed market acquirers.

Key words: intellectual capital, mergers and acquisitions, M\&A performance; developed markets; emerging markets JEL classification: G34, O34, O57 


\section{Introduction}

In the knowledge-based economy, mergers and acquisitions are likely to be one of the most popular growth strategies which allow firms to increase their production rates and performance, decrease costs, diversify their asset portfolio, or enter new markets.

Nowadays, intangible assets tend to play a greater role in company management. In the knowledge-based economy, intellectual capital is considered to be the key economic resource which forms the basis of operations of any company and influences its effective performance. The creation, development, and accumulation of skills, knowledge and expertise which form the intellectual capital of a firm is a primary corporate objective [1]. Intellectual capital plays a significant role in the increase of business performance [2] and may be one of the governing motives for mergers and acquisitions [3].

The majority of researchers agree that the intellectual capital of a target company should serve to increase the value of the acquirer as part of a mergers and acquisitions deal. However, the motives of companies operating in various capital markets differ, and in some papers the impact of intellectual capital or its components cannot be proven with statistical measurements. Some papers studying emerging capital markets have obtained contradictory results in terms of the kind of influence intellectual capital exerts on company value as a result of mergers and acquisitions. This confirms that further research in this field is necessary. As such, the problem of development of intellectual capital measurement methods which, undoubtedly, influence directly the obtained research results is still relevant.

None of the researchers in this area doubt that in the modern competitive environment, characterised by swift changes caused primarily by the development of technologies and innovations, that intangible assets may help a firm to retain or even enhance its competitive positions in the market.

In spite of a large number of papers which study various aspects of intellectual capital, research in the form of a comparative analysis of the influence of intellectual capital on M\&A performance vis-à-vis the performance of acquirers from developed and emerging capital markets is very scarce. Unlike previous academic papers, we include in the scope of our study an analysis of the impact of each component of intellectual capital (human, structural and relational capital) on the performance of such transactions. We also perform a comparative analysis of their influence on the value of acquirers in developed and emerging capital markets. For this analysis, we chose a period of transactions from 2010 to 2018 in order to distinguish the impact of intellectual capital and its components on M\&A performance for those companies which had to rearrange their operations due to modern technologies and innovations.

The remainder of the paper is structured as follows. In the first section we present a literature review including definitions of intellectual capital and its components. Here we also formulate our research hypotheses. The second section describes the research methodology, and the third one provides the sample used to test the research hypotheses. In the fourth section we discuss the obtained results, while in the fifth section we articulate our key conclusions.

\section{Definition of Intellectual Capital and its Components}

There are two main approaches to defining the intellectual capital of a firm: static and dynamic [4]. In accordance with the static approach, intellectual capital is defined as a reserve of external and internal resources owned by the company at a certain period of time [5]. As per the dynamic approach, intellectual capital also comprises activities aimed at using company resources, obtaining new knowledge, and creating firm value. Such activities include training company employees, R\&D, and IT management. These kinds of activities allow a company to increase and expand the existing reserves of intellectual capital, and to create new ones [6-8].

There is one additional approach to defining intellectual capital which distinguishes its two main characteristics. Firstly, intellectual capital is considered among the intangible assets of a firm which cannot exist independently from or be assessed separately from other assets. Secondly, intellectual capital is a result of the use of capital, organisational, intellectual, and human resources of a firm [9-11].

Most often in academic literature intellectual capital includes three key components: human, structural, and relational [12-14]. Human capital consists of those resources which include the implicit individual knowledge of employees, their skills, competences, experience, abilities, talent, and interpersonal relations [15]. Human capital helps a company to respond to changes in its external business environment and is the main source of its added value, innovations, and strategic vision [12]. Unlike human capital, structural capital belongs to a firm. It is defined as the knowledge which a firm possesses at the end of a working day [15]. On the one hand, structural capital comprises information systems, the technologies of a company, and its intellectual property (including patents, brands, trademarks, copyrights, and know-how) [16]. On the other hand, structural capital includes corporate culture and management methods which maintain the operations of a company [4]. The structural capital of a company inspires its human resources to create and use knowledge and to derive profit therefrom [15].

Relational capital includes resources related to the company's relations with its stakeholders [4]. It encompasses the company image, key customers' loyalty, and the trust of the principal suppliers and partners. Relational capital links human and structural capital to external counterparts [17]. Some authors distinguish the so-called consumer capital which characterises the relations of a company with its customers $[12 ; 15 ; 16]$. 
Companies always strive to replenish insufficient resources which are necessary for their successful operations. They often achieve this goal by acquiring the assets of another company through mergers and acquisitions. A significant part of the acquisition price, especially in knowledge-intensive industries, is the paid-for intellectual capital of the target company [18]. In order to most efficiently use the acquired strategic resources based on knowledge, skills, the expertise of employees, the intellectual property of the company, and its relations with customers it is necessary to be able to define and measure intellectual capital of both the acquirer and the target company.

\section{Literature Review of Impact of Intellectual Capital on M\&A Performance in Developed and Emerging Capital Markets}

The main methods used to measure M\&A performance from the perspective of intellectual capital are the questionnaire method, case studies, and the event studies method.

Researchers applying the questionnaire method consider intellectual capital to be one of the main efficiency determinants. They draw the conclusion that the acquisition and retention of intellectual capital of the target company is acknowledged by the management personnel of acquirers from developed capital markets to be one of the key determinants which improve M\&A performance $[3 ; 20]$. In order to achieve high results from mergers and acquisitions, companies aim to choose the target firm with the most valuable assets. One of the factors advertising for the value of the assets of the target is its reputation [21] which is a part of relational capital. For example, T. Saxton and M. Dollinger [21], using a selection of data on cross-border mergers and acquisitions closed in 1993 (where acquirers were 77 companies from developed markets) showed that the target company's reputation had a positive effect on the performance of mergers and acquisitions initiated by companies from developed markets.

C.M. Fong, C.L. Lee [22] and M. Matarazzo et al. [23] analysed the influence of reputation of the target firm on acquisition performance in terms of how the customers' attitude to the acquirer would change after accomplishing the transaction. The authors drew similar conclusions: acquisitions of firms with good reputations by developed market companies improve relations with customers and enhance customers' trust in the acquirer, thus resulting in the rise of its operational performance.

The human capital of target companies also plays a significant role in the acquisition process. For example, I. Nikandrou and N. Papalexandris [24], as well as Y. Weber et al. [25] proved that the acquisition by firms in developed markets of target companies with large investments in staff education and skill enhancement should lead to an increase in the performance of the acquirer.

Employees and top managers of the target company are an integral part of the human capital of a firm and are considered to be its strategic resource. M.F. Ahammad et al. [26] in their paper, studied the influence of retention of managers from the target company on the performance of cross-border mergers and acquisitions. Based on empirical data on transactions initiated by 65 British companies, and aimed at acquisitions in North America and Europe during the period of 2000 to 2004, they showed that the extent of retention of employees has a positive and significant impact on M\&A performance. Similar results were obtained in the earlier research dedicated to mergers and acquisitions performed by developed market companies [27-29].

Besides the quality of human capital and its retention, researchers also highlight the importance of the complementarity of human capital for success of mergers and acquisitions. The researchers manage to prove that such complementarity between the target company and the acquirer provides a developed market acquirer with benefits due to diversification, and increases its value as a result of mergers and acquisitions [28; 30].

The structural capital of the target company also plays an important role in mergers and acquisitions. For example, C. Francoeur [31] studied a long-term effect from mergers and acquisitions based on a database of 126 Canadian firms which were engaged in M\&As between 1990-2000, as well as the impact of structural capital on M\&A performance. The research reveals that mergers and acquisitions are more efficient when target companies are characterised by a high level of know-how and R\&D investments. A positive influence of $R \& D$ investments and a number of patents on M\&A performance was also identified, for example, in the paper by J. Bena and K. Li [32].

Academic papers studying the impact of intellectual capital on M\&A performance in emerging capital markets demonstrate controversial results. For example, S.A. Grigorieva and A. Yu. Grinchenko [33] as well as S. Weusthoff and R. Meckl [34] revealed a positive influence of intellectual capital on the performance of mergers and acquisitions. However, the research by S. Weusthoff and R. Meckl [34], which studied 365 cross-border mergers and acquisitions initiated by companies from the BRICS countries during the period of 2005 to 2013, found a positive but statistically insignificant impact of intellectual capital on performance of the deals. One potential explanation may be the fact that market players perceive the acquisition of intellectual capital as long-term investments of a firm, and this is invisible in the short-term intervals analysed by the researchers. In the paper by A.M. Arikan [35], who studied 158 mergers and acquisitions by emerging market companies during the period 1988-1991, identified that the concentration of intangible assets of the target company which describes its intellectual capital has a negative impact on the long-term cumulative abnormal returns of acquirers.

As far as intellectual capital components are concerned, a positive influence of relational, human and structural capital on M\&A performance was identified for companies from emerging as well as developed markets. For example, C.M. Fong, C.L. Lee and Y. Du [36], studying the impact of reputation as one of the determinants of relational capital in the success of mergers and acquisitions in 
Chinese companies for the period 2005 to 2010, conclude that the higher the reputation of the target company, the higher managers of the acquirer evaluate the performance of mergers and acquisitions. L. Chalencon et al. [37] came to the same conclusion in evaluating the relationship between reputation, a number of customers of the target firm, and the performance of mergers and acquisitions initiated by companies from emerging capital markets between 2010-2015.

Both emerging market and developed market firms, when selecting a target, pay attention to such strategic assets as technology, patents, databases, and other components of structural capital which affect M\&A performance.

Acquisition of companies with huge R\&D investments facilitates the accumulation of technology and innovation resources and the development of competitive advantages. The research of R. Srivastava and A. Prakash [41] proved a significant positive impact of $R \& D$ intensity on $M \& A$ performance on the basis of 187 mergers and acquisitions initiated by Indian pharmaceutical companies. A positive but statistically insignificant influence of R\&D intensity on M\&A performance was found by X. Wu et al. [40] using a selection of data on 180 cross-border mergers and acquisitions made by Chinese companies in 2002-2012, as well earlier by M. Hassan et al. [39].

The significance of intangible assets nowadays is likely to grow as they help a firm to retain its sustainable competitive advantages in the fast-changing competitive environment of developed and emerging capital markets. Investments in human capital, R\&D, information technologies, and advertisements, play an important role in maintaining the competitive positions of a company and in the achievement of its strategic goals and objectives [42]. One of the key motives of mergers and acquisitions of emerging market firms is to find developed market companies with a high quality of intellectual capital. As long as intellectual capital provides a company with a substantial competitive advantage over other market players, the acquisition of intellectual capital by means of mergers and acquisitions stimulates the performance of such M\&A transactions and raises the value of the acquirer [34; 43]. In developed markets, intellectual capital is also considered to be one of the major success factors of mergers and acquisitions. M\&A performance could also be affected by such factors as the similarity and complementarity of resources, the combination of knowledge, technologies, as well as customers and partners of companies which all describe intellectual capital [44]. Another determinant of M\&A performance is the amount of intangible assets owned by the target company, which could be integrated and used by the acquirer.

Thus, based on the analysis performed we hypothesise:

H1: in developed markets, M\&A performance increases when the level of intellectual capital of the target company rises;

H2: in emerging markets M\&A performance increases when the level of intellectual capital of the target company rises.
Human capital, which comprises the abilities, skills, experience, and knowledge of employees, is an important determinant of M\&A performance because it represents a strategic resource of a firm. There are two types of knowledge: explicit and implicit. While explicit knowledge may be expressed in writing in the documents of a firm, or recorded in digital form, implicit knowledge is based upon the practices and personal experiences of employees. As such, it is inseparable from its holder and, as a rule, has no tangible form. Both types of knowledge form the basis for company value creation. Implicit knowledge may be transferred to the acquirer only in the process of education, common projects, and collective work. This is directly connected with retention of employees in the target company in the case of mergers and acquisitions [26]. The more intensively a company uses human capital, the more significant is its influence on the company value. In this context, we can assume that the human capital of employees of the target company exerts an impact on the performance of mergers and acquisitions [39]. Human capital also includes company top management. Many experts assume that replacement of the company management with more qualified employees increases deal performance. However, in recent years the majority of the larger companies have tended to retain top management, and to avoid losing either the social or human capital or knowledge of the management team. They also try to decrease uncertainty regarding a new company for customers and employees of the target firm, and thus to raise the transaction performance level [26]. Expertise and education of top management and other employees of the company, as well as investments in education aimed at creation of human capital enhance firm performance and ensure its sustainable development.

The above mentioned helps us to generate the following research hypotheses:

H3: in developed markets $M \hookleftarrow A$ performance increases when the level of human capital of the target company rises;

H4: in emerging markets M\&A performance increases when the level of human capital of the target company rises. Relational capital includes not only the company's relations with its stakeholders, but also its reputation, the satisfaction of its customers with the company operations and products, and the firm image. The company's clients are the main party interested in its operations, and are considered to be one of its main sources of income. If a company is market- and customer-oriented, customer loyalty increases, thus stimulating company value growth due to steady cash flows and a reduction of investment risk [2]. Customer satisfaction facilitates the creation of competitive advantages and increases the company's market share. Relations with partners and customers, and channels of communication are recognised as firm assets which are able to increase its value. Sustainable relations with the partners and clients of a company help to improve a business model, allow for learning lessons from the experience of other companies, and thus assists 
in raising operations performance as a result of the successful management of assets. The reputation of a target company is also the key element of relational capital. The acquisition of a reputable company stimulates new customers and increases the loyalty of existing customers, thus providing access to new resources [21]. Networks of target companies become one of the determinants of mergers and acquisitions [34]. The existing external and internal relations which form the relational capital of a firm in both developed and emerging markets give a new company an opportunity to operate successfully, and promote its development and sustainable growth.

Thus, we formulate the fifth and sixth research hypotheses:

H5: in developed markets M\&A performance increases when the level of relational capital of the target company rises;

H6: in emerging markets M\&A performance increases when the level of relational capital of the target company rises.

Examples of structural capital are patents, trademarks, brands, and technologies. Brand acquisition tends to be one of the determinants of M\&A performance [34]. Brand value is especially important for companies from emerging capital markets because it gives them an opportunity to become more successful. However, there are not enough well-known brands in emerging capital markets, and so multinational companies buy brands in developed markets in order to improve client perception of these firms. As far as companies from developed markets are concerned, one of the main reasons of brand acquisition is the presence of new opportunities associated with the fact that the acquirer has patents. Foreign companies with patents which are in line with the operations of the acquirer are the most attractive assets to be acquired, because they raise the technology level of a new company and ensure economies of scale. If the technology portfolios of the target company and the acquirer are similar, it may result in a successful acquisition because the intellectual property of the target company may facilitate the further development of technologies and an extension of the current $\mathrm{R} \& \mathrm{D}$.

The acquisition of structural capital of the target company may lead to a more efficient manufacturing processes, an optimisation of business processes for the purpose of cost reduction and quality improvement, and an improvement of the operational indicators of the acquirer. Structural capital can have a positive effect on the financial indicators of a firm: its acquisition by means of mergers and acquisitions facilitates the income growth of the acquirer, and an increase of its return on assets and equity. Structural capital also plays an important role in company value creation [40].

The performed analysis helps us to formulate the following research hypotheses:

H7: in developed markets, M\&A performance increases when the level of structural capital of the target company rises;
H8: in emerging markets, MઐA performance increases when the level of structural capital of the target company rises.

Emerging market companies regard the acquisition of firms from developed markets as a new stage of their development. This allows such companies to enter new markets and attract customers of the target companies, but also to compensate for the gap in the level of intellectual capital. This gap represents a situation whereby it is insufficient for emerging market firms to participate in the global competition based on knowledge, new technologies and innovations. At the same time, for developed market companies characterised by a high level of intellectual capital development, the acquisition of companies from developed countries is just a way to reinforce their competitive position [34].

Consequently, we can suggest the last group of hypotheses:

H9: intellectual capital has a higher influence on M\&A performance for acquirers from emerging capital markets than for acquirers from developed capital markets;

H9a: human capital has a higher influence on MßA performance for acquirers from emerging capital markets than for acquirers from developed capital markets;

H9b: relational capital has a higher influence on M\&A performance for acquirers from emerging capital markets than for acquirers from developed capital markets;

H9c: structural capital has a higher influence on MßA performance for acquirers from emerging capital markets than for acquirers from developed capital markets.

\section{Methodology}

In order to define the nature of influence of intellectual capital on performance of mergers and acquisitions we perform an OLS regression analysis. To analyse the performance of mergers and acquisitions the event studies method is used, in which the cumulative abnormal return (CAR) is the dependent variable.

The most important component of the research based on calculation of the cumulative abnormal return is the selection of two-time intervals: the estimation period and the event window. Within the estimation period, "normal" returns are measured. For their evaluation, we use the market model based on the linear dependence between the market return and the return on the share:

$R_{i t}=\alpha_{i}+\beta_{i}^{*} R_{m t}$,

where $R_{m t}$ and $R_{i t}$ - market return and return on a share of a certain company on day $t$.

Coefficients $\alpha$ and $\beta$ are calculated in the estimation period. Consequently, we find "normal" returns $\widehat{R_{i t}}$ for each day t of the event window using the following formula:

$\widehat{R_{i t}}=\widehat{\alpha_{i}}+\widehat{\beta}_{i} * R_{m t}$.

To accurately measure the normal returns on shares it is necessary to choose an optimal estimation period: it 
should not be too long or too short. In the majority of papers dedicated to the analysis of the performance of mergers and acquisitions, researchers choose an estimation period of between 100 and 200 days. Therefore, in this paper we use the estimation period of 120 days up to the event window, which is used in the majority of the research studies we have reviewed.

Many researchers measure the performance of mergers and acquisitions, varying the length of the event window to perform a more comprehensive analysis, and to avoid the insignificance of cumulative abnormal returns due to a too-long window. In this research, we also use several event windows of $(+15,-15),(+5,-5)$ and $(+3,-3)$ based on our review of papers which use the event studies method to analyse the influence of intellectual capital on M\&A performance.

After choosing the estimation period and the length of the event window, we can calculate the cumulative abnormal return for shares of each company. First, it is necessary to calculate the actual return of shares and the market return per each day within the event window using the following formula:

$$
R_{i(m), t}=\ln \frac{p_{i(m), t}}{p_{i(m), t-1}},
$$

where $R_{i(m), t}$-actual market return (m) and shares of company $\mathrm{i}$ on day $\mathrm{t}$;

$p_{i(m), t}$ and $p_{i(m), t-1}$ - the closing price of shares of company $i$ and the market index on day $t$ and on the previous day $(\mathrm{t}-1)$ respectively.

The abnormal return $\left(A R_{i t}\right)$ is calculated as difference between the actual $\left(R_{i t}\right)$ and normal return $\left(\widehat{R_{i t}}\right)$ on the company shares on each day t within the event window:

$$
A R_{i t}=R_{i t}-\widehat{R_{i t}} \text {. }
$$

In order to get the cumulative abnormal return of the shares of each company, we finally need to obtain the sum of all the abnormal returns calculated for each day of the event window.

$$
C A R_{i}=\sum_{-t}^{t} A R_{i t} .
$$

\section{Intellectual Capital Measurement}

In this paper we use four variables to describe the intellectual capital of the firm. One variable reflects the intellectual capital of the firm in general. Three other variables represent its components: human, relational, and structural capital. Our basic research assumption is a hypothesis that all the components of intellectual capital characterise its various aspects, however, when put together they do not equal intellectual capital. See the results of checks for multicollinearity in Appendix 1 and 2.

K.E. Sveiby [19] postulates that in order to assess intellectual capital in terms of mergers and acquisitions it is necessary to use quantitative methods, and in particular ones based on the company's return on assets and market capitalisation methods. In our research we use a market capitalisation method, and intellectual capital is calculated as a difference between the book and market values of the company:

$$
\text { IC = Market value }- \text { Book value . (6) }
$$

To assess the components of intellectual capital we use

\begin{tabular}{|c|c|c|c|}
\hline $\begin{array}{l}\text { Intellectual capital } \\
\text { component }\end{array}$ & $\begin{array}{l}\text { Variable measurement } \\
\text { method }\end{array}$ & Description & Previous research \\
\hline Human capital & $\begin{array}{l}\text { Company sales } \\
\text { Number of employees }\end{array}$ & $\begin{array}{l}\text { Reflects average productivity and } \\
\text { performance of the company and its } \\
\text { employees and, consequently, of human } \\
\text { capital in general }\end{array}$ & $\begin{array}{l}\text { Dzinkowski, 2000; } \\
\text { Chen et al., 2005; } \\
\text { Kim et al., } 2016 \\
{[46-48]}\end{array}$ \\
\hline
\end{tabular}
proxy variables, which are based on publicly available data and which are presented in Table 1.

Table 1. Variables for the measurement of intellectual capital components

Corporate growth
Relational capital $\quad$ rates in sales
rates in sales
This indicator implies that the advantages of relational capital result in a growth in corporate sales

\section{Dzinkowski, 2000;}

Wang, Chang, 2005;

Garanina, 2011;

Kim et al., 2016

[46; 48-50] 


$\begin{array}{llll}\begin{array}{l}\text { Intellectual capital } \\ \text { component }\end{array} & \begin{array}{l}\text { Variable measurement } \\ \text { method }\end{array} & \text { Description } & \text { Previous research } \\ & \begin{array}{l}\text { SG \&A (Selling, General } \\ \text { and Administrative Ex- } \\ \text { penses) }\end{array} & \begin{array}{l}\text { Reflects corporate investments in } \\ \text { technological processes, research and } \\ \text { development, improvement of business }\end{array} & \begin{array}{l}\text { Garanina, 2011; } \\ \text { Sydler et al., 2014; } \\ \text { Scafarto et al. 2016 } \\ \end{array} \\ & \text { processes and company products } & \text { [47; 50-52] }\end{array}$

\section{Data and Sample}

The main source of information on mergers and acquisitions, indicators which characterise such transactions, and the financial status of the companies participating in them, is the Bloomberg database. We also used corporate annual reports to calculate the indicators related to human capital.

In the present article, we take into account mergers and acquisitions initiated by companies from developed and emerging capital markets in the period of 2010-2018.

Target companies are firms from developed countries. Emerging countries in which acquirers operate are analysed using Chinese, Indian, Brazilian, and Malaysian firms, because they are leaders in terms of the quantity of cross-border deals as well as their volume over the last 10 years. Developed countries are chosen based on the same criterion: USA, Canada, Germany, Great Britain, France, Italy, and Japan. Data on the quantity and volume of cross-border deals is taken from the statistical information provided by the Institute for Mergers, Acquisitions and Alliances [53].

To fall into the sample, all the transactions need to meet the following criteria:

- all transactions in the sample should be closed by the date of research;

- only cross-border mergers and acquisitions are analysed;

- mergers and acquisitions in which the acquirer or the target company belong to the financial sector are excluded from the sample. Such companies have a different structure of assets and obligations. They may be controlled by the government, which may have an impact on the results;

- the target company and the acquirer should be public companies because of the chosen methods of measurement of performance of mergers and acquisitions (event studies) and intellectual capital (the market capitalisation method);

- the acquired share should exceed $50 \%$ because acquisition of the controlling interest stipulates active integration into the target company and opportunities to take advantage of the acquisition of intellectual capital;

- availability of the data necessary to calculate the indicators of the regression model, for example, information on the number of the company employees.
Thus, the final sample comprises 194 mergers and acquisitions, of which 115 are initiated by companies from developed markets and 79 by companies from emerging markets.

In order to assess the influence of intellectual capital on the performance of mergers and acquisitions, the following regression model is used:

$$
\begin{aligned}
& \text { CAR }_{i}=\beta_{1}+\beta_{2} \text { IC }_{i}+\beta_{3} \text { HC }_{i}+ \\
& +\beta_{4} \text { SC }_{i}+\beta_{5} \text { RC }_{i}+\beta_{6} \text { Share }_{i}+ \\
& +\beta_{7} \text { Val }_{i}+\beta_{8} \text { ASize }_{i}+\beta_{9} \text { ROA }_{i}+ \\
& +\beta_{10} \text { Payment }_{i}+ \\
& +\Sigma B \cdot D_{\text {countries }}+I N N+\varepsilon_{i}
\end{aligned}
$$

where IC is a proxy variable which takes into consideration manifestations of the intellectual capital of a firm, and is calculated as a natural logarithm of the difference between the book and market value of the company;

HC is a proxy variable which takes into consideration manifestations of human capital of a firm and is calculated as a natural logarithm of the ratio between the total sales and the number of employees;

SC is a proxy variable which allows to take into consideration manifestations of structural capital of a firm and is calculated as a natural logarithm of the ratio between the total expenditures of a company and the number of employees;

RC is a proxy variable which allows to take into consideration manifestations of the relational capital of a firm and is calculated as sales growth rates of a firm;

Share is the share of the company which is acquired; Val is the transaction value which is calculated as a natural logarithm of the amount spent on mergers and acquisitions;

ASize is the size of the acquirer expressed as a natural logarithm of the total amount of its assets as of the date of the transaction announcement;

ROA is profitability of the acquirer's assets, which characterises its performance;

Payment is a dummy variable which measures the method used to pay for the transaction. It takes on a value of 1 if the transaction is paid in cash and 0 in all the other cases.

We also introduce control variables for the countries of the acquirers and industries: 
US, G, F, IT, UK, J are dummy variables for acquirers from the USA, Germany, France, Italy, Great Britain, and Japan, respectively;

CH, IN, BR, $M$ are dummy variables for acquirers from China, India, Brazil, and Malaysia, respectively;

INN is a dummy variable which takes on a value of 1 if the industry is innovative and 0 for all other industries.

Breakdown of industries into innovative and non-innovative is made on the basis of the UNIDO classification.

In order to test hypothesis 9 and its sub-hypotheses (stating that the effect of intellectual capital on the performance of mergers and acquisitions is greater when the transaction is initiated by a company from an emerging market), the model is tested based on the overall sample. In this case a new variable is used which measures joint influence of intellectual capital or one of its components, and the dummy variable which characterises whether the acquirer belongs to an emerging or developed capital market (Dev $=1$ if the acquirer is from a developed market, $\mathrm{Dev}=0$ if the acquirer is from an emerging market). For this purpose we introduce new variables, which are obtained by multiplying intellectual capital or its components by the dummy variable (IC_Dev = IC.Dev; HC_Dev $=$ HC.Dev; RC_Dev = RC.Dev; SC_Dev $=$ SC.Dev).

\section{Analysis of the Impact of Intellectual Capital on M\&A Performance}

Before testing the hypotheses, we calculated cumulative abnormal returns for all the companies to analyse the performance of cross-border mergers and acquisitions in developed capital markets. CAR was calculated for the whole sample, as well as for two sub-samples. The first sub-sample comprises transactions initiated by developed market firms and the second sub-sample includes transactions initiated by emerging market firms. The results of the calculations are presented in Table 2.

Table 2. Analysis of efficiency of mergers and acquisitions

\begin{tabular}{|c|c|c|c|}
\hline \multirow[b]{2}{*}{ Event window } & \multicolumn{3}{|c|}{ CAR value in \% (t-statistics) } \\
\hline & $\begin{array}{l}\text { The whole sample } \\
\text { (194 observations) }\end{array}$ & $\begin{array}{l}\text { Emerging markets } \\
\text { (79 observations) }\end{array}$ & $\begin{array}{l}\text { Developed markets } \\
\text { (115 observations) }\end{array}$ \\
\hline CAR $(-15+15)$ & $\begin{array}{l}-2.324 \\
(0.82)\end{array}$ & $\begin{array}{c}-4.145 \\
(0.96)\end{array}$ & $\begin{array}{c}1.08 \\
(1.24)\end{array}$ \\
\hline $\operatorname{CAR}(-5+5)$ & $\begin{array}{l}1.055 \\
(1.51)\end{array}$ & $\begin{array}{c}0.68 \\
(1.32)\end{array}$ & $\begin{array}{c}2.86 \\
(1.79)^{*}\end{array}$ \\
\hline $\operatorname{CAR}(-3+3)$ & $\begin{array}{c}2.332 \\
(1.77)^{*}\end{array}$ & $\begin{array}{c}1.14 \\
(1.56)\end{array}$ & $\begin{array}{c}3.039 \\
(2.19)^{* *}\end{array}$ \\
\hline
\end{tabular}

Significance levels: ${ }^{\star} 10 \%$; ${ }^{*} 5 \%$; ${ }^{* *} 1 \%$.

Source: authors' own calculations.

On average, mergers and acquisitions aimed at the acquisition of a developed market firm are efficient within the event window of $(-3,+3)$ where the cumulative abnormal return is significant and equals $2.332 \%$. If we compare transactions by the acquirer's origin, we may say that transactions initiated by companies from developed countries create a greater value in two short windows than transactions where the acquirer operates in an emerging market. This may be explained by the fact that when companies from emerging markets enter developed markets through mergers and acquisitions they face more serious cultural and institutional constraints. In the window of $(-3,+3)$ the market response to mergers and acquisitions is positive and statistically significant: at the $10 \%$ significance level for the overall sample and at the $5 \%$ significance level for developed markets. At the long event window of $(-15,+15)$ all cumulative returns are insignificant. This may be a result of a too-long event window, which takes into account other corporate events and may distort the obtained results.

We use the event window of $(-3,+3)$ to test the rest of the hypotheses. Besides, the seven days event window of $(-3$, +3 ) was used by R. Meckl and S. Weusthoff [34] when they analysed the impact of intellectual capital on performance of cross-border mergers and acquisitions in which the acquirer from an emerging market enters a developed market. In addition, we used the Chow test to check whether the sample should be assessed as a whole or divided into two sub-samples. The results of the Chow test are given in Appendix 3. 
Table 3. Results of testing the influence of the intellectual capital in developed and emerging capital markets (complete testing results are presented in Appendix 4)

$$
\text { For the event window of }(-3,+3)
$$

\begin{tabular}{|c|c|c|}
\hline Variables & $\begin{array}{l}\text { Developed } \\
\text { markets }\end{array}$ & $\begin{array}{l}\text { Emerging } \\
\text { markets }\end{array}$ \\
\hline Constant & -0.04905 & -0.03603 \\
\hline IC & $0.06950^{\star}$ & $0.07206^{\star}$ \\
\hline $\mathrm{HC}$ & $0.04978^{\star *}$ & $0.05388^{\star \star}$ \\
\hline $\mathrm{RC}$ & $0.00895^{\star}$ & 0.00819 \\
\hline SC & 0.00867 & 0.00782 \\
\hline ROA & 0.22598 & 0.16804 \\
\hline
\end{tabular}

\begin{tabular}{ccc} 
Payment & $\mathbf{0 . 0 7 5 3 5 ^ { * * }}$ & 0.04568 \\
\hdashline Val & 0.14825 & $\mathbf{0 . 1 7 9 2 6}^{*}$ \\
\hdashline ASize & 0.00434 & 0.00854 \\
\hdashline Share & 0.03574 & 0.07135
\end{tabular}

$\begin{array}{ll}\text { US } & 0.00816\end{array}$

\begin{tabular}{|c|c|}
\hline G & -0.00528 \\
\hline F & -0.00494 \\
\hline IT & -0.00685 \\
\hline UK & 0.00546 \\
\hline J & 0.00088 \\
\hline
\end{tabular}

\begin{tabular}{|c|c|c|}
\hline $\mathrm{CH}$ & & 0.02971 \\
\hline IN & & 0.00907 \\
\hline BR & & 0.00736 \\
\hline INN & 0.01259 & 0.01138 \\
\hline $\mathrm{R}^{2}$ & 0.4226 & 0.4182 \\
\hline
\end{tabular}

Significance level: ${ }^{*} 10 \% ;{ }^{*} 5 \%$; ${ }^{* *} 1 \%$.

Source: authors' own calculations.

As we can see from Table 3, the intellectual capital of the target company has a positive effect on the cumulative abnormal return at the $10 \%$ significance level for acquirers both from developed and emerging markets. The higher the level of intellectual capital of the target, the higher the performance of a deal for the acquirer. Thus, hypotheses 1 and 2 about the positive influence of intellectual capital on performance of transactions cannot be rejected at the $10 \%$ significance level. Similar results about a significant and positive influence of intellectual capital on the perfor- mance of mergers and acquisitions were also obtained in other papers which study mergers and acquisitions initiated by companies from developed markets $[3 ; 14 ; 20]$ and emerging markets [33]. Intellectual capital is considered by many researchers to be one of the key determinants of M\&A performance. However, our results differ from the results obtained by R. Meckl and S. Weusthoff [34] and A.M. Arikan [35] who showed that influence of intellectual capital for companies from emerging countries was in the first case positive but insignificant and in the second case - negative. The differences of our results and the results of the research by A.M. Arikan may be explained by the long-term event window he used [35].

Our results demonstrate that the impact of human capital on M\&A performance is positive. The coefficient of influence of human capital is significant at the $5 \%$ level for companies from emerging as well as from developed capital markets. So, hypotheses 3 and 4 cannot be rejected. The obtained results correspond with the previous research studies in the field which managed to prove a significant positive relation between human capital and the performance of mergers and acquisitions initiated by companies from developed markets $[24 ; 26]$ and emerging markets [38; 39]. The obtained results may be explained by the fact that employees who are highly qualified, well experienced, who have attended various training programs, lectures and workshops, who have knowledge on specificities of the firm operations, who are also self-motivated and who strive to work for the benefit of the company are a special strategic asset in favour of firm performance and, consequently, serve to improve its indicators, for example revenue growth.

In the current paper, we managed to empirically identify a positive relationship between the relational capital of the target company and the cumulative abnormal return at the $10 \%$ significance level for companies from developed countries. For companies from emerging markets we also found a positive relationship between relational capital of the target company and cumulative abnormal return. However, it was statistically insignificant. A positive impact of relational capital on M\&A performance was found earlier in the research of C.-M. Fong, C.-L. Lee and Y. Du [36] and L. Chalencon [37] for emerging capital markets. T. Saxton and M. Dollinger [21] in their research also identified that the reputation of the target company has a positive impact on success of mergers and acquisitions in developed markets. The positive impact of relational capital on performance of mergers and acquisitions may be explained as follows: a good reputation of the target company means that customers as well as partners highly appreciate and trust in the target firm, which directly influences its performance. Therefore the acquisition of such a company makes the acquirer, when it enters a new market, use the existing reputation of the target company to strengthen its competitive position and to expand its presence. Besides this, a large and solid database of customers and suppliers owned by the target company comes into the possession of the acquirer after the M\&A deal. 
This is an additional benefit for the acquirer. Thus, hypothesis 5 on the positive influence of relational capital on the performance of mergers and acquisitions in developed markets cannot be rejected. In hypothesis 6, the impact of relational capital on the performance of mergers and acquisitions in emerging markets tends to be statistically insignificant.

We also identify a positive relationship between the structural capital of the target company and M\&A performance; however, it is statistically insignificant for both developed and emerging markets. Thus, hypotheses 7 and 8 are rejected. The main reason for the positive influence of structural capital is that acquisition of patented technologies, and the scientific and technological knowledge bases of the target company (which complement the technology and knowledge base of the acquirer) stimulates an increase in R\&D efficiency and, consequently, makes mergers and acquisitions more successful [54]. The obtained results correspond with other research studies in which authors find a positive influence of various components of structural capital, such as patents [32], investments in R\&D [38; 40; 41], and the level of know-how [31], on M\&A performance for companies in emerging as well as developed markets.

In order to test hypothesis 9 and its sub-hypotheses we test four regression models based on the overall sample using our new variables, as described in the section dedicated to our research methodology. The results of the regressions are presented in Table 4.

Table 4. Results of comparative analysis of impact of intellectual capital on M\&A performance in developed and emerging capital markets (see complete results in Appendix 5)

\begin{tabular}{|c|c|c|c|c|}
\hline Variables & Model 1 & Model 2 & Model 3 & Model 4 \\
\hline Constant & -0.03595 & -0.05118 & -0.05909 & -0.04749 \\
\hline IC & $0.07721^{\star}$ & $0.07021^{\star}$ & $0.08175^{\star}$ & $0.06983^{\star}$ \\
\hline $\mathrm{HC}$ & $0.04997^{\star}$ & $0.05186^{* *}$ & $0.05407^{* *}$ & $0.04745^{\star}$ \\
\hline $\mathrm{RC}$ & $0.00722^{* *}$ & $0.00653^{\star}$ & $0.00707^{\star}$ & $0.00626^{*}$ \\
\hline SC & $0.00511^{\star}$ & 0.00532 & 0.00642 & $0.00502 *$ \\
\hline IC_Dev & -0.00256 & & & \\
\hline HC_Dev & & $-0.00411 * *$ & & \\
\hline RC_Dev & & & 0.00028 & \\
\hline SC_Dev & & & & $0.00185 *$ \\
\hline ROA & 0.19848 & 0.12979 & 0.15997 & 0.16892 \\
\hline Payment & $0.06390 *$ & $0.06603 *$ & 0.07080 & $0.05867^{\star *}$ \\
\hline Val & $\mathbf{0 . 1 5 7 2 8 ^ { \star }}$ & 0.16580 & 0.15716 & 0.16990 \\
\hline ASize & -0.00412 & 0.00508 & 0.00644 & 0.00464 \\
\hline Share & 0.06887 & 0.05406 & 0.06790 & 0.06417 \\
\hline US & 0.00617 & 0.00676 & 0.00780 & 0.00714 \\
\hline G & -0.00503 & -0.00498 & -0.00443 & -0.00519 \\
\hline $\mathrm{F}$ & -0.00464 & -0.00446 & -0.00410 & -0.00497 \\
\hline IT & -0.00714 & -0.00767 & -0.00641 & -0.00653 \\
\hline UK & 0.00638 & 0.00778 & 0.00719 & 0.00638 \\
\hline J & 0.00087 & 0.00077 & 0.00083 & 0.00080 \\
\hline $\mathrm{CH}$ & -0.00198 & -0.00182 & -0.00152 & -0.00161 \\
\hline IN & -0.00818 & -0.00781 & -0.00742 & -0.00786 \\
\hline $\mathrm{BR}$ & -0.00936 & -0.00870 & -0.00826 & -0.00927 \\
\hline M & -0.01354 & -0.01273 & -0.01199 & -0.01232 \\
\hline INN & 0.01263 & 0.01317 & 0.01111 & 0.01079 \\
\hline $\mathrm{R}^{2}$ & 0.3831 & 0.3929 & 0.3869 & 0.4016 \\
\hline
\end{tabular}

Significance levels: ${ }^{\star} 10 \% ;{ }^{* \star} 5 \% ;{ }^{* *} 1 \%$.

Source: authors' own calculations. 
As we can see from Table 4, the coefficient of the variable IC_Dev is negative $(\beta=-0.00256)$. This confirms that a positive effect of intellectual capital is higher for companies from emerging markets than for companies from developed markets. However, the p-value is 0.2808 , which implies the statistical insignificance of this coefficient and, correspondingly, the insignificance of the difference in the influence of intellectual capital on the performance of mergers and acquisitions for both markets. Thus, hypothesis 9 is rejected.

When checking model 2, the variable HC_Dev has a negative coefficient, which is statistically significant at the $5 \%$ level $(\beta=-0.00411)$. This means that there are differences in the effect of human capital for two sub-samples, and these differences are significant. The negative sign preceding the coefficient means that the degree of impact of human capital on the success of a transaction is higher for companies from emerging markets than for companies from developed markets. Consequently, hypothesis 9 a cannot be rejected at the $5 \%$ significance level. The obtained results may stem from the fact that developed markets are characterised by a high intensity of human capital, and mergers and acquisitions between competing companies may demotivate employees to develop innovative solutions. Consequently, a positive effect from the acquisition of such human capital will be lower [55].

The coefficient of the variable which describes the joint influence of relational capital and the dummy variable turned out to be positive, but low $(\beta=0.00028)$. This means that relational capital influences the performance of mergers and acquisitions a little more when the acquirer operates in a developed market. However, this difference is statistically insignificant ( $p$-value $=0.1879$ ). Thus, hypothesis $9 \mathrm{~b}$ is rejected. In other words, we can conclude that relational capital equally influences M\&A performance for companies in both emerging and developed capital markets. Relations with customers and their loyalty are important for every company, irrespective of the market the company belongs to. This is because such customers significantly define the company's operations. That is why acquisition of firms with a high level of relational capital, expressed in a large customer database and customer trust, improves M\&A performance irrespective of the acquirer's country of origin [56].

The results of the testing of model 4 shows that the coefficient of the fictitious variable SC_Dev is positive ( $\beta$ $=0.00185)$ and significant at the $10 \%$ level. This proves that for companies from developed markets, structural capital has a stronger impact on performance of mergers and acquisitions than for companies from emerging markets, although we initially anticipated the opposite effect. Thus, hypothesis $9 \mathrm{c}$ is rejected. The obtained result, from our point of view, may be explained by the fact that when companies from emerging markets enter developed markets, they may acquire firms with which they have no technological interconnection, or with which such interconnection is very low. Technology and patents represent a specific part of the structural capital of the target company, and do not influence the innovative activity of the acquirer. This reduces the positive effect of structural capital of the target company for acquirers from emerging markets when compared with acquirers from developed markets [57].

\section{Conclusion}

In this paper, in contrast to the previous studies, we conduct a comparative analysis of the influence of intellectual capital in general and its key components (human, relational, and structural) on the performance of mergers and acquisitions in developed and emerging capital markets. We compare developed markets based on firms from the USA, Canada, Germany, Great Britain, France, Italy, and Japan, and emerging markets based on firms from China, India, Brazil, and Malaysia.

Based on the evaluation of empirical data, we show that the performance of mergers and acquisitions for an acquirer positively and statistically significantly depends on the intellectual capital of the target company, irrespective of the market in which the acquirer operates. The larger the intellectual capital of the target firm, the higher the level of performance of mergers and acquisitions for an acquirer both in developed and emerging capital markets. Each component of intellectual capital of the target company increases the performance of the acquisition: the higher the level of human, relational, or structural capital of the target company, the higher the M\&A performance for the acquirer. We have managed to prove a positive and statistically significant relationship for acquirers in developed capital markets for human and relational capital. For emerging markets, we have proven this only for human capital.

The results of the analysis performed allow us to conclude that in general, transactions initiated by companies from developed countries create a greater value for the acquirer than transactions in which the acquirer operates in an emerging capital market.

The comparative analysis of influence of intellectual capital and its components on M\&A performance allows us to make the following conclusions:

There is no significant difference in the influence of intellectual capital on M\&A performance for developed and emerging capital markets.

Relational capital has the same impact on M\&A performance for companies in emerging markets, as well as in developed markets.

The influence of human capital on M\&A performance is higher for acquirers from emerging capital markets, while the influence of structural capital is higher for acquirers from developed capital markets.

Further areas of potential research may include an enlargement of the sample of countries, the use of alternative methods of measurement of intellectual capital and its components to test our research hypotheses, the use of a different time period or duration, and the study of 
the influence of the intellectual capital of the acquirer on the performance of mergers and acquisitions. It seems reasonable to expand the scope of the future research by adding domestic mergers and acquisitions and by avoiding studying mergers and acquisitions only in developed capital markets. The chosen indicator of measurement of acquisition performance may also influence the obtained results. In future research studies, it may conceivably be replaced with ROA, ROE, and EVA.

\section{References}

1. Baiburina E.R., Ivashkovskaya I.V. The role of intellectual capital in creating value of Russian companies. Vestnik Finansovoi akademii = Bulletin of the Financial Academy. 2007;(4):53-62. (In Russ.).

2. Bhasin M.L. Measurement and disclosure of intellectual capital: Evidence from a developing country. International Journal of Finance and Accounting. 2012;1(5):82-93. DOI: 10.5923/j. ijfa.20120105.02

3. Bertoncelj A., Kovač D. An integrated approach for a higher success rate in mergers and acquisitions. Zbornik radova Ekonomskog fakulteta u Rijeci: Časopis za ekonomsku teoriju i praksu = Proceedings of Rijeka Faculty of Economics: Journal of Economics and Business. 2007;25(1):167-188.

4. Mention A.-L. Intellectual capital, innovation and performance: A systematic review of the literature. Business and Economic Research. 2012;2(1). DOI: 10.5296/ber.v2i1.1937

5. Choo C.W., Bontis N. Knowledge, intellectual capital, and strategy: Themes and tensions. In: Choo C.W., Bontis N., eds. The strategic management of intellectual capital and organizational knowledge. New York: Oxford University Press; 2002:3-19. URL: http://choo.fis.utoronto.ca/oup/SMICOKchap1.pdf

6. Marr B., Moustaghfir K. Defining intellectual capital: A three-dimensional approach. Management Decision. 2005;43(9):1114-1128. DOI: $10.1108 / 00251740510626227$

7. Kianto A. What do we really mean by the dynamic dimension of intellectual capital? International Journal of Learning and Intellectual Capital. 2007;4(4):342-356. DOI: 10.1504/IJLIC.2007.016332

8. Stam C.D. Ideas and things: Understanding the dynamic dimension of intellectual capital. In: Proc. $2^{\text {nd }}$ European conf. on intellectual capital (Lisbon, Mar. 29-30). Lisbon: Lisbon University Institute; 2010:529-535.

9. Daum J.H. Intangible assets and value creation. Chichester: John Wiley \& Sons; 2003. 443 p.

10. Firer S., Mitchell Williams S. Intellectual capital and traditional measures of corporate performance.
Journal of Intellectual Capital. 2003;4(3):348-360. DOI: $10.1108 / 14691930310487806$

11. Jurczak J. et al. Intellectual capital measurement methods. Economics and Organization of Enterprise. 2008;1(1):37-45. DOI: 10.2478/v10061-008-0005-y

12. Bontis N. Intellectual capital: An exploratory study that develops measures and models. Management Decision. 1998;36(2):63-76. DOI: 10.1108/00251749810204142

13. Peña I. Intellectual capital and business start-up success. Journal of Intellectual Capital. 2002;3(2):180198. DOI: $10.1108 / 14691930210424761$

14. Bonardo D., Paleari S., Vismara S. The M\&A dynamics of European science-based entrepreneurial firms. The Journal of Technology Transfer. 2010;35(1):141-180. DOI: 10.1007/s10961-009-91093

15. Edvinsson L., Malone M.S. Intellectual capital: The proven way to establish your company's real value by finding its hidden brainpower. London: Piatkus Books; 1997. 240 p.

16. Stewart T., Ruckdeschel C. Intellectual capital: The new wealth of organizations. Performance Improvement. 1998;37(7):56-59. DOI: 10.1002/ pfi.4140370713

17. Knight D.J. Performance measures for increasing intellectual capital. Strategy \& Leadership. 1999;27(2):22-27. DOI: 10.1108/eb054632

18. Marr B., Gray D., Neely A. Why do firms measure their intellectual capital? Journal of Intellectual Capital. 2003;4(4):441-464. DOI: 10.1108/14691930310504509

19. Sveiby K.E. The new organizational wealth: Managing \& measuring knowledge-based assets. San Francisco, CA: Berrett-Koehler Publishers; 1997. 275 p.

20. Lemieux O.P., Banks J.C. High tech M\&A - strategic valuation. Management Decision. 2007;45(9):14121425. DOI: DOI: $10.1108 / 00251740710828672$

21. Saxton T., Dollinger M. Target reputation and appropriability: Picking and deploying resources in acquisitions. Journal of Management. 2004;30(1):123147. DOI: $10.1016 /$ j.jm.2003.01.006

22. Fong C.M., Lee C.L. Reputation spillover effects and post-acquisition performance: A customer perspective. In: Finkelstein S., Cooper C.L., eds. Advances in mergers and acquisitions. Vol. 11. Bingley: Emerald Group Publishing Ltd.; 2012:139154.

23. Matarazzo M. et al. Cultural distance, reputation transferability and cross-border acquisitions: A consumer perspective. In: Verbeke A., Puck J., Tulder R.v., eds. Distance in international business: 
Concept, cost and value (Progress in International Business Research. Vol. 12). Bingley: Emerald Group Publishing Ltd.; 2017:495-515.

24. Nikandrou I., Papalexandris N. The impact of M\&A experience on strategic HRM practices and organisational effectiveness: Evidence from Greek firms. Human Resource Management Journal. 2007;17(2):155-177. DOI: 10.1111/j.17488583.2007.00031.x

25. Weber Y., Rachman-Moore D., Tarba S.Y. HR practices during post-merger conflict and merger performance. International Journal of Cross Cultural Management. 2012;12(1):73-99. DOI: $10.1177 / 1470595811413111$

26. Ahammad M.F. et al. Knowledge transfer and cross-border acquisition performance: The impact of cultural distance and employee retention. International Business Review. 2016;25(1.Pt.A):66-75. DOI: 10.1016/j.ibusrev.2014.06.015

27. Krishnan H.A., Miller A., Judge W.Q. Diversification and top management team complementarity: Is performance improved by merging similar or dissimilar teams? Strategic Management Journal. 1997;18(5):361-374. DOI: 10.1002/(SICI)10970266(199705)18:5<361::AID-SMJ866>3.0.CO;2-L

28. Krug J.A., Aguilera R.V. Top management team turnover in mergers and acquisitions. In: Advances in Mergers and Acquisitions. Vol. 4. Bingley: Emerald Group Publishing Ltd.; 2004:121-149. DOI: 10.1016/ S1479-361X(04)04005-0

29. Butler F.C., Perryman A.A., Ranft A.L. Examining the effects of acquired top management team turnover on firm performance post-acquisition: A meta-analysis. Journal of Managerial Issues. 2012;24(1):47-60.

30. Lee K.H., Mauer D.C., Xu E.Q. Human capital relatedness and mergers and acquisitions. Journal of Financial Economics. 2018;129(1):111-135. DOI: 10.1016/j.jfineco.2018.03.008

31. Francoeur C. The long-run performance of crossborder mergers and acquisitions: Evidence to support the internalization theory. Corporate Ownership \& Control. 2006;4(2):312-323. DOI: 10.22495/ cocv $4 \mathrm{i} 2 \mathrm{c} 2 \mathrm{p} 8$

32. Bena J., Li K. Corporate innovations and mergers and acquisitions. The Journal of Finance. 2014;69(5):19231960. DOI: $10.1111 /$ jofi.12059

33. Grigorieva S.A., Grinchenko A.Yu. Impact of mergers and acquisitions in financial sector on bidders' returns in emerging capital markets. Korporativnye finansy = Journal of Corporate Finance Research 2013;7(4):53-71. (In Russ.). DOI: 10.17323/j. jcfr.2073-0438.7.4.2013.53-71
34. Weusthoff S., Meckl R. M\&A by EMNCs in developed countries: Motivation, success and implications. In: Brennan L., Bakir C., eds. Emerging market multinationals in Europe. Abingdon, New York: Routledge; 2016:65-78.

35. Arikan A.M. Does it pay-off to capture intangible assets through mergers and acquisitions? Academy of Management Annual Meeting Proceedings. 2002;(1):R1-R6. DOI: 10.5465/APBPP.2002.7516539

36. Fong C.-M., Lee C.-L., Du Y. Target reputation transferability, consumer animosity, and crossborder acquisition success: A comparison between China and Taiwan. International Business Review. 2013;22(1):174-186. DOI: 10.1016/j. ibusrev.2012.03.004

37. Chalençon L. et al. Reputation, e-reputation, and value-creation of mergers and acquisitions. International Studies of Management \& Organization. 2017;47(1):4-22. DOI: $10.1080 / 00208825.2017 .1241086$

38. Kaur B.P., Kaur G. Impact of mergers on the cost efficiency of Indian commercial banks. Eurasian Journal of Business and Economics. 2010;3(5):27-50.

39. Hassan M. et al. Do mergers and acquisitions create shareholder wealth in the pharmaceutical industry? International Journal of Pharmaceutical and Healthcare Marketing. 2007;1(1):58-78. DOI: 10.1108/17506120710740289

40. Wu X. et al. Cross-border mergers and acquisitions by Chinese firms: Value creation or value destruction? Journal of Contemporary China. 2016;25(97):130-145. DOI: 10.1080/10670564.2015.1060769

41. Srivastava R., Prakash A. Value creation through cross-border mergers and acquisitions by the Indian pharmaceutical firms. Journal of Strategy and Management. 2014;7(1):49-63. DOI: 10.1108/JSMA03-2013-0017

42. Cañibano L., Garsio-Ayuso M., Sánchez P. Accounting for intangibles: A literature review. Journal of Accounting Literature. 2000;19(1):102-130.

43. Dyr T., Ziółkowska K. The intellectual capital as the regions' competitiveness factor. Central European Review of Economics \& Finance. 2017;17(1):33-51. DOI: $10.24136 /$ ceref.2017.002

44. Boyle J., Winter M. A different toolbox for M\&A due diligence in China. Thunderbird International Business Review. 2010;52(1):55-59. DOI: 10.1002/ tie.20310

45. Forte W. et al. MtB versus VAIC in measuring intellectual capital: Empirical evidence from Italian listed companies. African Journal of Business Management. 2019;13(17):588-601. DOI: 10.5897/ AJBM2019.8840 
46. Dzinkowski R. The value of intellectual capital. Journal of Business Strategy. 2000;21(4):3-4.

47. Chen M.C., Cheng S.J., Hwang Y. An empirical investigation of the relationship between intellectual capital and firms' market value and financial performance. Journal of Intellectual Capital. 2005;6(2):159-176. DOI: 10.1108/14691930510592771

48. Kim T. et al. Intellectual capital and business performance: What structural relationships do they have in upper-upscale hotels? International Journal of Tourism Research. 2012;14(4):391-408. DOI: 10.1002/ jtr. 1868

49. Wang W.-Y., Chang C. Intellectual capital and performance in causal models: Evidence from the information technology industry in Taiwan. Journal of Intellectual Capital. 2005;6(2):222-236. DOI: $10.1108 / 14691930510592816$

50. Garanina T.A. Intellectual capital structure and value creation of a company: Evidence from Russian companies. Open Journal of Economic Research. 2011;1(2):22-34. URL: https://dspace.spbu.ru/ bitstream/11701/1453/1/Garanina\%20_\%20 Intellectual\%20Capital.pdf

51. Sydler R., Haefliger S., Pruksa R. Measuring intellectual capital with financial figures: Can we predict firm profitability? European Management Journal. 2014;32(2):244-259. DOI: 10.1016/j. emj.2013.01.008

52. Scafarto V., Ricci F., Scafarto F. Intellectual capital and firm performance in the global agribusiness industry: The moderating role of human capital. Journal of Intellectual Capital. 2016;17(3):530-552. DOI: 10.1108/JIC-11-2015-0096

53. M\&A statistics. Institute for Mergers, Acquisitions and Alliances. 2019. URL: https://imaa-institute.org/ mergers-and-acquisitions-statistics/

54. Makri M., Hitt M.A., Lane P.J. Complementary technologies, knowledge relatedness, and invention outcomes in high technology mergers and acquisitions. Strategic Management Journal. 2010;31(6):602-628. DOI: 10.1002/smj.829

55. Fulghieri P., Sevilir M. Mergers, spinoffs, and employee incentives. The Review of Financial Studies. 2011;24(7):2207-2241. DOI: 10.1093/rfs/hhr004

56. Rogan M., Sorenson O. Picking a (poor) partner: A relational perspective on acquisitions. Administrative Science Quarterly. 2014;59(2):301-329. DOI: $10.1177 / 0001839214531719$
57. Homburg C., Bucerius M. Is speed of integration really a success factor of mergers and acquisitions? An analysis of the role of internal and external relatedness. Strategic Management Journal. 2006;27(4):347-367. DOI: 10.1002/smj.520

58. Feruleva N., Ivashkovskaya I. Assessment of intellectual capital influence on corporate value as a field for further investigations in corporate finance. Korporativnye finansy = Journal of Corporate Finance Research. 2018;12(1):64-76. DOI: 10.17323/j. jcfr.2073-0438.12.1.2018.64-76 


\section{Appendices}

\section{Appendix 1. Correlation matrix: checking for multicollinearity}

\begin{tabular}{|c|c|c|c|c|c|c|c|c|c|c|c|c|c|c|c|c|c|c|c|c|}
\hline & IC & HC & $\mathbf{R C}$ & SC & ROA & Payment & Val & Asize & Share & US & G & $\mathbf{F}$ & IT & UK & $\mathrm{J}$ & $\mathrm{CH}$ & IN & BR & $\mathbf{M}$ & INN \\
\hline IC & 1 & & & & & & & & & & & & & & & & & & & \\
\hline HC & 0.022 & 1 & & & & & & & & & & & & & & & & & & \\
\hline RC & 0.1871 & 0.3399 & 1 & & & & & & & & & & & & & & & & & \\
\hline SC & 0.0484 & 0.3254 & 0.4187 & 1 & & & & & & & & & & & & & & & & \\
\hline ROA & 0.01 & $\mid-0.231$ & $\mid-0.022$ & 0.0936 & 1 & & & & & & & & & & & & & & & \\
\hline Payment & -0.205 & 0.1623 & 0.2068 & 0.1373 & 0.4177 & 1 & & & & & & & & & & & & & & \\
\hline Val & 0.3027 & 0.0826 & 0.2107 & $\mid 0.162$ & $\mid-0.075$ & $\mid-0.182$ & 1 & & & & & & & & & & & & & \\
\hline Asize & 0.4103 & 0.125 & 0.348 & 0.2738 & 0.2887 & 0.2758 & 0.4731 & 1 & & & & & & & & & & & & \\
\hline Share & -0.174 & -0.3 & $\mid-0.205$ & 0.181 & -0.084 & 0.0116 & $\mid-0.371$ & $\mid-0.016$ & 1 & & & & & & & & & & & \\
\hline US & 0.0213 & $\mid 0.1735$ & 0.2126 & 0.1407 & 0.2198 & 0.2229 & $\mid-0.105$ & $\mid-0.015$ & -0.254 & 1 & & & & & & & & & & \\
\hline G & 0.1811 & 0.1404 & $\mid-0.053$ & 0.0582 & 0.103 & 0.1512 & 0.201 & 0.3084 & $\mid-0.147$ & $\mid-0.118$ & 1 & & & & & & & & & \\
\hline F & -0.153 & 0.3999 & 0.4319 & 0.1704 & 0.0632 & 0.1048 & 0.2121 & 0.2768 & 0.0096 & $\mid-0.082$ & -0.055 & 1 & & & & & & & & \\
\hline IT & -0.198 & $\mid-0.109$ & $|-0.064|$ & $\mid-0.103$ & 0.1544 & 0.1521 & 0.179 & 0.0912 & -0.17 & 0.119 & -0.08 & $\mid-0.058$ & 1 & & & & & & & \\
\hline UK & 0.1531 & 0.0034 & 0.2139 & 0.0255 & -0.18 & $\mid-0.378$ & 0.0353 & 0.1293 & 0.0227 & $\mid-0.147$ & $\mid-0.1$ & $\mid-0.065$ & $\mid-0.104$ & 1 & & & & & & \\
\hline J & 0.2701 & 0.1908 & $\mid-0.097$ & $\mid-0.162$ & 0.2018 & $\mid-0.094$ & $\mid-0.405$ & $\mid-0.343$ & 0.0567 & $\mid-0.149$ & -0.111 & $\mid-0.06$ & -0.111 & $\mid-0.125$ & 1 & & & & & \\
\hline $\mathrm{CH}$ & 0.206 & 0.1333 & 0.0218 & 0.0488 & $\mid-0.109$ & $\mid-0.028$ & $\mid-0.004$ & |0-.078 & 0.4091 & $\mid-0.174$ & $\mid-0.118$ & -0.082 & -0.123 & -0.151 & $\mid-0.147$ & 1 & & & & \\
\hline IN & 0.1357 & 0.1344 & -0.081 & 0.2533 & $\mid-0.035$ & 0.1512 & 0.1602 & 0.2817 & $\mid-0.101$ & $\mid-0.12$ & $\mid-0.08$ & -0.053 & -0.081 & -0.112 & $\mid-0.11$ & -0.117 & 1 & & & \\
\hline BR & -0.206 & 0.0825 & $\mid 0.4389$ & $\mid-0.011$ & $\mid-0.178$ & 0.1514 & $\mid-0.066$ & 0.0712 & 0.0626 & $\mid-0.115$ & $\mid-0.087$ & $\mid-0.064$ & $\mid-0.079$ & $\mid-0.109$ & $\mid-0.103$ & $\mid-0.119$ & -0.08 & 1 & & \\
\hline M & -0.056 & 0.1127 & 0.0839 & $\mid-0.09$ & -0.221 & $\mid-0.367$ & 0.1183 & $\mid-0.181$ & $\mid-0.159$ & $\mid-0.082$ & $\mid-0.057$ & $\mid-0.038$ & -0.049 & -0.072 & $\mid-0.069$ & -0.082 & -0.063 & $\mid-0.055$ & 1 & \\
\hline INN & 0.2349 & 0.0023 & 0.0083 & 0.0437 & 0.2131 & $\mid-0.043$ & 0.1089 & $\mid-0.107$ & 0.1962 & 0.3423 & 0.1262 & 0.3022 & 0.1262 & 0.2294 & 0.2869 & 0.2706 & -0.192 & $\mid-0.184$ & -0.127 & 1 \\
\hline
\end{tabular}

Source: authors' calculations. 


\section{Appendix 2. Calculation of VIF: checking for multicollinearity}

\begin{tabular}{|c|c|c|}
\hline Variable & VIF & 1/VIF \\
\hline ROA & 3.962 & 0.2524156 \\
\hline Val & 3.055 & 0.3273397 \\
\hline SC & 2.937 & 0.3404734 \\
\hline $\mathrm{HC}$ & 2.453 & 0.4076633 \\
\hline $\mathrm{IC}$ & 2.331 & 0.4290367 \\
\hline Share & 1.872 & 0.5343265 \\
\hline $\mathrm{RC}$ & 1.838 & 0.5440498 \\
\hline Payment & 1.811 & 0.5523271 \\
\hline Asize & 1.764 & 0.5670479 \\
\hline US & 1.680 & 0.5951308 \\
\hline UK & 1.645 & 0.6078579 \\
\hline $\mathrm{F}$ & 1.596 & 0.6266431 \\
\hline IT & 1.586 & 0.6304499 \\
\hline IN & 1.557 & 0.6421820 \\
\hline G & 1.468 & 0.6812418 \\
\hline INN & 1.292 & 0.7741054 \\
\hline BR & 1.205 & 0.8295493 \\
\hline M & 1.176 & 0.8503839 \\
\hline $\mathrm{CH}$ & 1.027 & 0.9734574 \\
\hline $\mathrm{J}_{\ldots}$ & 0.937 & 1.0669077 \\
\hline Average VIF & 1.860 & 0.5377581 \\
\hline
\end{tabular}

Source: authors' calculations.

Appendix 3. Chow test: checking whether the sample should be divided into two subsamples

\begin{tabular}{|c|c|c|}
\hline $\mathbf{R S S}_{\mathrm{ALL}}$ & 69.861 & 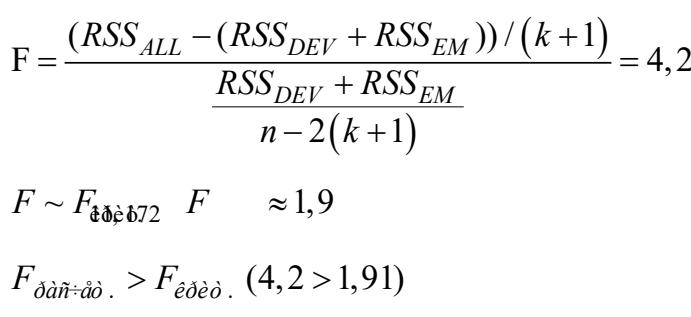 \\
\hline RSS $_{\text {DEVELOPED }}$ & 32.014 & \\
\hline RSS $_{\text {EMERGING }}$ & 23.052 & \\
\hline F-statistics & 4.2 & \\
\hline
\end{tabular}

Source: authors' calculations. 


\section{Appendix 4. Results of testing influence of intellectual capital in developed and emerging capital markets}

Developed markets

Regression statistics

\begin{tabular}{|c|c|c|c|c|c|c|}
\hline Multiple R & 0.650069449 & & & & & \\
\hline $\mathrm{R}^{2}$ & 0.422590289 & & & & & \\
\hline Adjusted $\mathrm{R}^{2}$ & 0.331704051 & & & & & \\
\hline Standard error & 0.557947064 & & & & & \\
\hline Observations & 115 & & & & & \\
\hline \multicolumn{7}{|c|}{ Analysis of variance } \\
\hline & $D f$ & SS & MS & $F$ & Significance $F$ & \\
\hline Regression & 16 & 22.3278804 & 1.395492525 & 4.482719064 & $5.29742 \mathrm{E}-06$ & \\
\hline Residual & 98 & 30.50788272 & 0.311304926 & & & \\
\hline \multirow[t]{2}{*}{ Total } & 114 & 52.83576313 & & & & \\
\hline & Coefficient & Standard error & t-stat. & $P$-value & Lower 95\% & Upper 95\% \\
\hline Const & -0.049052704 & 0.064540388 & -0.760031131 & 0.29748133 & -0.177488075 & 0.079382668 \\
\hline IC & 0.069500549 & 0.035422527 & 1.962043764 & 0.059088491 & -0.000990281 & 0.139991378 \\
\hline $\mathrm{HC}$ & 0.049776291 & 0.023105425 & 2.154311823 & 0.040280718 & 0.003796495 & 0.095756087 \\
\hline RC & 0.008954912 & 0.004612202 & 1.941569984 & 0.061429748 & -0.000223369 & 0.018133194 \\
\hline SC & 0.008669882 & 0.005948884 & 1.457396411 & 0.137673874 & -0.003168397 & 0.020508162 \\
\hline ROA & 0.22598316 & 0.140772211 & 1.605310861 & 0.110104102 & -0.054153541 & 0.506119861 \\
\hline Payment & 0.07535423 & 0.031181945 & 2.416598112 & 0.022670046 & 0.013302159 & 0.137406302 \\
\hline Val & 0.148254118 & 0.101285492 & 1.463725115 & 0.136421426 & -0.053304011 & 0.349812247 \\
\hline Asize & 0.004336407 & 0.002723167 & 1.592413378 & 0.112362295 & -0.001082695 & 0.009755509 \\
\hline Share & 0.0357393 & 0.039120416 & 0.913571585 & 0.261513527 & -0.042110327 & 0.113588928 \\
\hline US & 0.008158412 & 0.013768079 & 0.592559923 & 0.333361552 & -0.019240065 & 0.035556889 \\
\hline G & -0.005279547 & 0.007605143 & -0.694207522 & 0.312136783 & -0.020413781 & 0.009854687 \\
\hline $\mathbf{F}$ & -0.004936586 & 0.005477385 & -0.901267065 & 0.264455057 & -0.015836582 & 0.005963409 \\
\hline IT & -0.006846426 & 0.009246728 & -0.740416114 & 0.30191103 & -0.025247415 & 0.011554562 \\
\hline UK & 0.005455365 & 0.007226993 & 0.754859592 & 0.298653956 & -0.008926351 & 0.019837081 \\
\hline J & 0.000877834 & 0.000782397 & 1.121980988 & 0.211552164 & -0.000679135 & 0.002434803 \\
\hline INN & 0.012586112 & 0.007912941 & 1.590573189 & 0.112686815 & -0.003160641 & 0.028332865 \\
\hline
\end{tabular}




\section{Emerging markets}

Regression statistics

Multiple R

0.646698602

$\begin{array}{ll}\text { Adjusted } \mathrm{R}^{2} & 0.301862898\end{array}$

0.418219082

Standard error $\quad 0.641332657$

Observations

79

Analysis of variance

Regression
Residual
Total

Df $\quad$ SS

Const.
IC
HC
RC
SC
ROA
Payment
Val
Asize
Share
CH
IN
BR
INN

13
65
78 SS MS

MS

F

Significance $F$

19.21871904

1.478363003

3.594300434

0.000854268

Coefficient

26.73499252

0.411307577

Standard error

t-stat.

-value

Lower 95\%

Upper 95\%

0.03275391

$-1.10008597$

0.216202742

$-0.101212399$

0.029148164

0.072059789

0.038906979

1.852104432

0.072808789

$-0.0053651$

0.149484678

0.05388422

0.022620336

2.3821145

0.025102452

0.008869762

0.098898697

0.008186552

0.005543443

$0.168040505 \quad 0.17732544 \quad 0.947639015$

1.476799014

0.133739908

$-0.002844901$

0.019218004

0.031452929

0.947639015
1.452371045

0.123782081

$-0.002357424$

0.01800668

0.1792557

0.008538914

0.071348506

0.098288801

0.029706669

0.0095688

1.823765841

0.252692604

$-0.18483712$

0.52091813

$-0.016910005$

$-0.016338956$

0.10827265

$0.076562674 \quad-0.016338956 \quad 0.374850471$

0.00906788

0.007361809

0.04989555

0.265905003

$-0.010502997$

0.027580825

0.143000308

$-0.027943638$

0.17064065

\begin{tabular}{l}
0.009067883 \\
0.007361809 \\
\hline 0.011375011
\end{tabular}

0.023651548

1.256013736

0.180118538

$-0.017359911$

0.07677325

Source: authors' calculations.

0.010300945

0.714673167

0.306947419

$-0.005991834$

0.0241276

0.011375011

0.013809459

0.823711609

0.282107035

$-0.013137072$

0.02786069

$-0.016105811$

0.038855834 


\section{Appendix 5. Comparative analysis of influence of intellectual capital on performance of mergers and acquisitions in developed and emerging capital markets (for hypothesis 9 )}

\begin{tabular}{|c|c|c|c|c|c|c|}
\hline Regression sta & & & & & & \\
\hline Multiple R & 0.618938277 & & & & & \\
\hline $\mathrm{R}^{2}$ & 0.383084591 & & & & & \\
\hline Adjusted $\mathrm{R}^{2}$ & 0.307763524 & & & & & \\
\hline Standard error & 0.624148487 & & & & & \\
\hline Observations & 194 & & & & & \\
\hline Analysis of var & & & & & & \\
\hline & $d f$ & SS & MS & $F$ & Significance $F$ & \\
\hline Regression & 21 & 41.60766614 & 1.981317435 & 5.086021805 & 2.38863E-09 & \\
\hline Residual & 172 & 67.00454931 & 0.389561333 & & & \\
\hline Total & 193 & 108.6122155 & & & & \\
\hline & Coefficient & Standard error & t-stat. & $P$-value & Lower 95\% & Upper 95\% \\
\hline Const. & -0.035948979 & 0.037649705 & -0.954827633 & 0.252163063 & -0.110871892 & 0.038973934 \\
\hline IC & 0.07721218 & 0.039949669 & 1.932736422 & 0.06210821 & -0.002287661 & 0.15671202 \\
\hline HC & 0.049970463 & 0.042017273 & 1.837629485 & 0.074110826 & -0.006402194 & 0.160826553 \\
\hline RC & 0.00721667 & 0.003379221 & 2.135601794 & 0.041412804 & 0.000492021 & 0.01394132 \\
\hline SC & 0.005111264 & 0.002991993 & 1.708314237 & 0.092946381 & -0.000842802 & 0.01106533 \\
\hline ROA & 0.198475639 & 0.229655049 & 0.864233726 & 0.273843091 & -0.258537909 & 0.655489186 \\
\hline Payment & 0.063902348 & 0.034100237 & 1.873956143 & 0.069344449 & -0.003957123 & 0.13176182 \\
\hline Val & 0.157278763 & 0.081629755 & 1.926733256 & 0.062820605 & -0.005164449 & 0.319721974 \\
\hline Asize & -0.004116709 & 0.003573384 & -1.152047693 & 0.204887321 & -0.011227744 & 0.002994326 \\
\hline Share & 0.068871007 & 0.048534046 & 1.419024637 & 0.145558214 & -0.027711744 & 0.165453758 \\
\hline Dev_IC & -0.00255924 & 0.003066045 & -0.834703955 & 0.280810567 & -0.00866067 & 0.00354219 \\
\hline US & 0.006174563 & 0.004347557 & 1.420237145 & 0.145309337 & -0.002477077 & 0.014826202 \\
\hline G & -0.005028748 & 0.00706166 & -0.7121198 & 0.308804075 & -0.01908145 & 0.009023955 \\
\hline $\mathbf{F}$ & -0.004642301 & 0.00577431 & -0.803957632 & 0.287988236 & -0.016133177 & 0.006848576 \\
\hline IT & -0.007138163 & 0.005416077 & -1.317958109 & 0.167032521 & -0.017916157 & 0.003639831 \\
\hline UK & 0.006378967 & 0.003979417 & 1.602990325 & 0.110460975 & -0.001540073 & 0.014298008 \\
\hline J & 0.000866138 & 0.001593011 & 0.543711251 & 0.34337411 & -0.002303953 & 0.004036229 \\
\hline $\mathrm{CH}$ & -0.001976816 & 0.001539379 & -1.284164205 & 0.174509823 & -0.00504018 & 0.001086549 \\
\hline IN & -0.008175792 & 0.011340693 & -0.720925281 & 0.306856402 & -0.030743771 & 0.014392187 \\
\hline BR & -0.009358891 & 0.02182808 & -0.428754665 & 0.363203383 & -0.052796771 & 0.034078988 \\
\hline M & -0.013543681 & 0.015551514 & -0.870891453 & 0.272263682 & -0.044491194 & 0.017403833 \\
\hline
\end{tabular}




\begin{tabular}{|c|c|c|c|c|c|c|}
\hline \multicolumn{7}{|c|}{ Regression statistics } \\
\hline Multiple R & 0.626850219 & & & & & \\
\hline $\mathrm{R}^{2}$ & 0.392941197 & & & & & \\
\hline Adjusted $\mathrm{R}^{2}$ & 0.318823552 & & & & & \\
\hline Standard error & 0.619142325 & & & & & \\
\hline Observations & 194 & & & & & \\
\hline \multicolumn{7}{|c|}{ Analysis of variance } \\
\hline & $d f$ & SS & MS & $F$ & Significance $F$ & \\
\hline Regression & 21 & 42.67821395 & 2.032295902 & 5.301587757 & 7.48874E-10 & \\
\hline Residual & 172 & 65.93400151 & 0.383337218 & & & \\
\hline \multirow[t]{2}{*}{ Total } & 193 & 108.6122155 & & & & \\
\hline & Coefficient & Standard error & $t$-stat. & $P$-value & Lower 95\% & Upper 95\% \\
\hline Const. & -0.051177265 & 0.062873324 & -0.813974226 & 0.28565944 & -0.176295179 & 0.073940649 \\
\hline IC & 0.070211376 & 0.029070055 & 1.783970568 & 0.081570155 & -0.005989287 & 0.109709533 \\
\hline HC & 0.051860123 & 0.029498425 & 2.380173694 & 0.024147873 & 0.01150951 & 0.128913242 \\
\hline RC & 0.006529514 & 0.003342176 & 1.953671236 & 0.059670638 & -0.000121417 & 0.013180444 \\
\hline SC & 0.005317155 & 0.00355994 & 1.493607823 & 0.130667959 & -0.001767126 & 0.012401436 \\
\hline ROA & 0.129787061 & 0.081975244 & 1.583247021 & 0.113958977 & -0.033343675 & 0.292917797 \\
\hline Payment & 0.066028826 & 0.039133528 & 1.687269945 & 0.096290243 & -0.011846895 & 0.143904547 \\
\hline Val & 0.165803885 & 0.105399291 & 1.573102475 & 0.115782291 & -0.043940704 & 0.375548474 \\
\hline Asize & 0.00508021 & 0.004327285 & 1.173994803 & 0.199734135 & -0.003531087 & 0.013691506 \\
\hline Share & 0.05405547 & 0.03913164 & 1.381375012 & 0.153392793 & -0.023816494 & 0.131927434 \\
\hline Dev_HC & -0.004107939 & 0.001677807 & -2.448397105 & 0.020572579 & -0.007446775 & -0.000769102 \\
\hline US & 0.006762765 & 0.004219466 & 1.602753844 & 0.110502476 & -0.001633972 & 0.015159501 \\
\hline G & -0.004980674 & 0.006519192 & -0.764001657 & 0.297172912 & -0.017953866 & 0.007992519 \\
\hline $\mathbf{F}$ & -0.004460577 & 0.003700249 & -1.205480339 & 0.192407868 & -0.011824073 & 0.002902918 \\
\hline IT & -0.007670648 & 0.011686724 & -0.656355684 & 0.320852145 & -0.030927228 & 0.015585933 \\
\hline UK & 0.007779737 & 0.005684119 & 1.368679388 & 0.156080097 & -0.00353166 & 0.019091134 \\
\hline $\mathrm{J}$ & 0.000768344 & 0.000741538 & 1.036147859 & 0.232553247 & -0.000707318 & 0.002244005 \\
\hline $\mathrm{CH}$ & -0.00181669 & 0.001237513 & -1.468016887 & 0.135679472 & -0.004279342 & 0.000645961 \\
\hline IN & -0.007812249 & 0.006086849 & -1.283463548 & 0.174666281 & -0.019925078 & 0.004300581 \\
\hline BR & -0.008700966 & 0.012580059 & -0.691647513 & 0.313286602 & -0.033735283 & 0.016333351 \\
\hline M & -0.012725535 & 0.017191227 & -0.740234244 & 0.302546517 & -0.046936077 & 0.021485007 \\
\hline INN & 0.013173431 & 0.012819446 & 1.027613164 & 0.234609565 & -0.012337266 & 0.038684129 \\
\hline
\end{tabular}




\begin{tabular}{|c|c|c|c|c|c|c|}
\hline \multicolumn{7}{|c|}{ Regression statistics } \\
\hline Multiple R & 0.622011662 & & & & & \\
\hline $\mathrm{R}^{2}$ & 0.386898507 & & & & & \\
\hline Adjusted $\mathrm{R}^{2}$ & 0.312043092 & & & & & \\
\hline Standard error & 0.622216179 & & & & & \\
\hline Observations & 194 & & & & & \\
\hline \multicolumn{7}{|c|}{ Analysis of variance } \\
\hline & $d f$ & SS & $M S$ & $F$ & Significance $F$ & \\
\hline Regression & 21 & 42.02190403 & 2.001043049 & 5.168610824 & $9.74051 \mathrm{E}-08$ & \\
\hline Residual & 172 & 66.59031142 & 0.387152973 & & & \\
\hline \multirow[t]{2}{*}{ Total } & 193 & 108.6122155 & & & & \\
\hline & Coefficient & Standard error & t-stat. & $P$-value & Lower 95\% & Upper 95\% \\
\hline Const. & -0.059093191 & 0.070673599 & -0.836142387 & 0.28047273 & -0.199733653 & 0.08154727 \\
\hline IC & 0.081752246 & 0.046083844 & 1.773989315 & 0.083013268 & -0.009954603 & 0.173459095 \\
\hline $\mathrm{HC}$ & 0.054065694 & 0.022309173 & 2.423473696 & 0.021823501 & 0.00967044 & 0.098460949 \\
\hline RC & 0.007069251 & 0.004087773 & 1.729364782 & 0.089679705 & -0.001065418 & 0.01520392 \\
\hline SC & 0.006419828 & 0.004326921 & 1.483694254 & 0.132596975 & -0.002190745 & 0.015030402 \\
\hline ROA & 0.159966898 & 0.103625833 & 1.543697103 & 0.121166008 & -0.046248509 & 0.366182305 \\
\hline Payment & 0.070801381 & 0.046890304 & 1.509936478 & 0.127525224 & -0.022510325 & 0.164113087 \\
\hline Val & 0.157159698 & 0.102293054 & 1.536367258 & 0.122530622 & -0.046403478 & 0.360722875 \\
\hline Asize & 0.006435034 & 0.004338199 & 1.483342198 & 0.132665769 & -0.002197983 & 0.015068051 \\
\hline Share & 0.06790184 & 0.051560196 & 1.316943007 & 0.167255104 & -0.034702951 & 0.17050663 \\
\hline Dev_RC & 0.000276836 & 0.000226019 & 1.224836471 & 0.187947242 & -0.000172941 & 0.000726614 \\
\hline US & 0.007804307 & 0.006024447 & 1.295439475 & 0.171999874 & -0.004184343 & 0.019792956 \\
\hline G & -0.00443361 & 0.00673363 & -0.658427905 & 0.320413921 & -0.017833532 & 0.008966313 \\
\hline $\mathbf{F}$ & -0.004100883 & 0.005101618 & -0.803839657 & 0.288015606 & -0.014253102 & 0.006051337 \\
\hline IT & -0.00641162 & 0.009746883 & -0.657812342 & 0.320544179 & -0.025807918 & 0.012984678 \\
\hline UK & 0.007193147 & 0.00773087 & 0.930444742 & 0.258029764 & -0.008191284 & 0.022577579 \\
\hline $\mathrm{J}$ & 0.000834763 & 0.000727375 & 1.14763801 & 0.205926887 & -0.000612713 & 0.002282238 \\
\hline CH & -0.001522611 & 0.001340809 & -1.135591354 & 0.208773464 & -0.00419082 & 0.001145599 \\
\hline IN & -0.007424845 & 0.012293894 & -1.058753047 & 0.331663844 & -0.031889694 & 0.017040004 \\
\hline BR & -0.00825558 & 0.013669406 & -0.603945748 & 0.331663844 & -0.035457698 & 0.018946539 \\
\hline M & -0.011988551 & 0.016148028 & -0.742415806 & 0.302056345 & -0.044123128 & 0.020146025 \\
\hline INN & 0.011112975 & 0.007588055 & 1.464535346 & 0.136369276 & -0.003987255 & 0.026213204 \\
\hline
\end{tabular}




\begin{tabular}{|c|c|c|c|c|c|c|}
\hline \multicolumn{7}{|c|}{ Regression statistics } \\
\hline Multiple R & 0.633749396 & & & & & \\
\hline $\mathrm{R}^{2}$ & 0.401638297 & & & & & \\
\hline Adjusted $\mathrm{R}^{2}$ & 0.328582508 & & & & & \\
\hline Standard error & 0.614691216 & & & & & \\
\hline Observations & 194 & & & & & \\
\hline \multicolumn{7}{|c|}{ Analysis of variance } \\
\hline & $d f$ & SS & MS & $F$ & Significance $F$ & \\
\hline Regression & 21 & 43.62282529 & 2.077277395 & 5.497692947 & $2.62727 \mathrm{E}-10$ & \\
\hline Residual & 172 & 64.98939016 & 0.377845292 & & & \\
\hline \multirow[t]{2}{*}{ Total } & 193 & 108.6122155 & & & & \\
\hline & Coefficient & Standard error & $t$-stat. & $P$-value & Lower 95\% & Upper 95\% \\
\hline Const. & -0.047492782 & 0.070426636 & -0.674358244 & 0.317019592 & -0.187641787 & 0.092656223 \\
\hline IC & 0.069828053 & 0.0364885 & 1.913700265 & 0.06438795 & -0.002784063 & 0.142440169 \\
\hline HC & 0.047447143 & 0.02573176 & 1.843913657 & 0.073270013 & -0.003759059 & 0.098653345 \\
\hline RC & 0.006262081 & 0.003271781 & 1.913967137 & 0.064355571 & -0.000248763 & 0.012772925 \\
\hline SC & 0.005018485 & 0.002537753 & 1.977531246 & 0.056980238 & $-3.16426 \mathrm{E}-05$ & 0.010068612 \\
\hline ROA & 0.168924486 & 0.17021581 & 0.992413602 & 0.24309943 & -0.169804977 & 0.507653948 \\
\hline Payment & 0.058671241 & 0.023820057 & 2.463102476 & 0.019863162 & 0.011269328 & 0.106073154 \\
\hline Val & 0.169903533 & 0.158736831 & 1.070347264 & 0.224330764 & -0.145982761 & 0.485789826 \\
\hline Asize & 0.004640388 & 0.002948824 & 1.573640258 & 0.115685193 & -0.001227771 & 0.010508547 \\
\hline Share & 0.064166616 & 0.072898602 & 0.88021737 & 0.270046628 & -0.080901603 & 0.209234835 \\
\hline Dev_SC & 0.001845255 & 0.001078859 & 1.710375624 & 0.092623035 & -0.000301675 & 0.003992184 \\
\hline US & 0.007144595 & 0.004459708 & 1.602032197 & 0.110629182 & -0.001730223 & 0.016019413 \\
\hline G & -0.00519258 & 0.010324534 & -0.502936002 & 0.350811519 & -0.025738402 & 0.015353242 \\
\hline $\mathbf{F}$ & -0.004973451 & 0.004761321 & -1.044552766 & 0.230529614 & -0.014448479 & 0.004501577 \\
\hline IT & -0.006525007 & 0.009704139 & -0.672394231 & 0.317440465 & -0.025836244 & 0.012786229 \\
\hline UK & 0.006375776 & 0.006191604 & 1.029745542 & 0.234095678 & -0.005945515 & 0.018697067 \\
\hline $\mathrm{J}$ & 0.000795572 & 0.000891758 & 0.892138683 & 0.267205255 & -0.000979027 & 0.002570171 \\
\hline $\mathrm{CH}$ & -0.001610255 & 0.001751348 & -0.919437456 & 0.260672425 & -0.005095437 & 0.001874928 \\
\hline IN & -0.007858714 & 0.007049685 & -1.114760976 & 0.213716764 & -0.021887588 & 0.00617016 \\
\hline BR & -0.009266674 & 0.017762027 & -0.521712644 & 0.347438678 & -0.044613107 & 0.026079759 \\
\hline M & -0.012316435 & 0.025011782 & -0.492425311 & 0.352659467 & -0.062089881 & 0.037457012 \\
\hline INN & 0.010787998 & 0.007432361 & 1.451490084 & 0.138970774 & -0.0040024 & 0.025578395 \\
\hline
\end{tabular}

